This article was downloaded by: [130.132.123.28]

On: 03 February 2015, At: 20:24

Publisher: Routledge

Informa Ltd Registered in England and Wales Registered Number: 1072954

Registered office: Mortimer House, 37-41 Mortimer Street, London W1T

3J H, UK

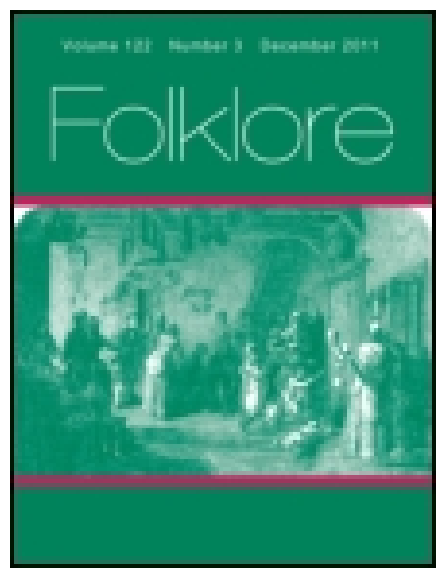

\title{
Folklore
}

Publication details, including instructions for authors and subscription information:

http:// www. tandfonline.com/loi/ rfol20

\section{Manipuri Proverbs}

\section{J. Shakespear}

Published online: 06 Feb 2012.

To cite this article: J . Shakespear (1911) Manipuri Proverbs, Folklore, 22:4, 473-475, DOI: $10.1080 / 0015587 X .1911 .9719499$

To link to this article: http:// dx. doi.org/ 10.1080/ 0015587X.1911.9719499

\section{PLEASE SCROLL DOWN FOR ARTICLE}

Taylor \& Francis makes every effort to ensure the accuracy of all the information (the "Content") contained in the publications on our platform. However, Taylor \& Francis, our agents, and our licensors make no representations or warranties whatsoever as to the accuracy, completeness, or suitability for any purpose of the Content. Any opinions and views expressed in this publication are the opinions and views of the authors, and are not the views of or endorsed by Taylor \& Francis. The accuracy of the Content should not be relied upon and should be independently verified with primary sources of information. Taylor and Francis shall not be liable for any losses, actions, claims, proceedings, demands, costs, expenses, damages, and other liabilities whatsoever or howsoever caused arising directly or indirectly in connection with, in relation to or arising out of the use of the Content.

This article may be used for research, teaching, and private study purposes. Any substantial or systematic reproduction, redistribution, reselling, loan, sub-licensing, systematic supply, or distribution in any form to anyone is 
expressly forbidden. Terms $\&$ Conditions of access and use can be found at http://www.tandfonline.com/page/terms-and-conditions 
brought this upon him. Because he took the meat he brought bad luck upon him.

A. J. N. TREMEARNE.

\section{Manipuri Proverbs.}

THE following twenty proverbs in use among the Manipuris have been collected by Mr. H. J. Wince, Headmaster of the Johnstone School, Imphal. $\Lambda \mathrm{n}$ exact translation and the nearest English equivalent or an explanation follow each proverb.

\section{J. Sulikespiar.}

I. Cheiren chaphubu kainaba yeibra ?

Are the Cheiren pots beaten to break them? (i.e. Spare the rod and spoil the child. Cheiren is a place in Mranipur where the best pottery can be obtained, and pots are beaten to shape them, not formed on wheels as in England).

2. Nungshit sittana una lengbra?

Without the breeze blowing can the leaves tremble? (i.e. There is no smoke without there being a fire).

3. Leppa challaga phamba challi.

Phamba challaga hippa challi.

After providing standing room [he] wants sitting room; after sitting room he desires sleeping room, (i.e. The more he gets the more he wants).

4. Huinan macha challaga leiton leki.

If you show much affection for a pup he will lick the tip of your tongue, (i.e. Give him an inch, he'll take an ell. The Manipuris do not love dogs, but regard them as causes of defilement. This proverb is used when a mean or low man is encouraged and does not know where to draw the line).

5. Khong chotlaga chin chotli.

If you wet your feet (or legs) you wet your mouth. (The staple food of the Manipuris is fish, and to get it they have to get into water with their traps or nets.) 
6. Hi ani tonglaga karãng segai. When going in two boats, [one leg in each], you tear the fork [of the leg], (i.e. Between two stools one comes to the ground).

7. Nung anigi marakta hă onba.

You become a yam when placed between two stones, (i.e. When a man acts as a go-between for two enemies he is in danger of becoming unfriendly to both).

8. Tingkhangbu tingkhanghanba.

To get out one thorn [that has pierced you] by inserting another [into the flesh], (i.e. Set a thief to catch a thief).

9. Ngaprum makhunda ngaprum thajinba. ${ }^{1}$

To set one eel into the hole of another eel, (i.e. Set a thief to catch a thief).

10. Uchi kallaktuna yum mei thăba.

Setting [one's] house on fire to spite a rat, (i.e. To cut off one's nose to spite one's face).

I1. Sabina mama noknaba.

A young mole laughing at its mother, (i.e. The pot calling the kettle black).

12. Haudong tuminleiba chaphu ngammi.

A quiet cat can [slyly] come and eat what the [rice] pot contains, (i.e. Still waters run deep).

13. Sendāng nganna tãbana machangchai.

The early sparrow gets the best rice to eat, (i.e. The early bird catches the fattest worm).

14. Khumdrabadi yărabani.

If you do not reply, you are agreeable, (i.e. Silence gives consent).

15. Una mahei yăllaga maru luki.

A tree that bears much fruit droops its head, (i.e. $\Lambda$ big or

2This is found also in Primrose's list of Meithel proverbs, Grammar, pp. 91 et seg. T. C. 11. 
very clever person is always humble, but it is not 80 with foolish people, who are very proud).

16. Huibu dolai tonghallaga thigang uraga chongthei.

$A$ dog, when made to ride a palanquin, jumps down on seeing a dung-heap, (i.e. What's bred in the bones will come out in the flesh. Among the Manipuris riding a palky is considered a great honour, as only certain people are permitted to do it).

17. Lamboibada samjet pibagum.

Like giving an ascetic a comb, (i.e. Casting pearls before swine. Hindu ascetics in Manipur shave their heads, so that a comb is thrown away on them).

18. Sal asibagi manakta leplaga prachit phangi.

When [found] standing near a dead cow you receive penance. (Hindus do not kill, but worship, the cow, so that, if they are found near others killing a cow, they are included among the company of evil-doers.)

19. Pena semlingeida Samuran yauba.

While tuning the pena (an instrument like a fiddle), I might have reached Samuran. (Samuran is a village in the south of Manipur near IVangoi, and the idea here is a protest against waste of time in profitless preliminaries.)

20. Khutta paiba itāugi yada hukpa eigi.

What I hold in my hands is my friend's, what I hold in my tecth mine, (i.e. $\Lambda$ bird in the hand is worth two in the bush).

1Or, alternatively, a tree that bears much froit has deep roots. T. C. II.

- Prachis = prajas thhifta, a purificatory penance. The proverb meana that you cannot touch pitch without being defiled, and a/so includes the idea that birds of a feather flock together. T. C. II. 